\title{
Oksana Shachko (1987-2018), co-founder of FEMEN
}

\section{Gender, feminism, and performative protest}

This last July, FEMEN co-founder Oksana (or Oxana) Shachko was found dead in her apartment in the Paris suburbs from what appears to have been a suicide. ${ }^{1}$ Shachko was a revolutionary feminist who offered her body for her cause; she was also an artist, trained and practiced in painting Orthodox icons from her childhood. Born in western Ukraine amidst the post-Soviet economic devastation, she had wanted to dedicate her life to the church and then to communism before committing to feminism in her late teens. ${ }^{2}$ She had been forced to flee to France in 2013 when Ukrainian authorities (under the administration of pro-Russia President Viktor Yanukovych) launched proceedings against FEMEN for terrorism. They had found some weapons and a portrait of Vladimir Putin with a target, which FEMEN alleges had been planted. By most accounts, Shachko was a person whose full-bodied beliefs ordered her life, leaving little room for self-care. Outside of Ukraine, she seems to have gotten lost, disconnecting from FEMEN and struggling to find a new role by returning to her Orthodox-related art. According to one of her closest friends, it was exile that killed her. ${ }^{3}$

FEMEN has received a tremendous amount of attention and sparked much controversy over the last decade, but Shachko's death is good moment to consider FEMEN from her perspective. Phenomena such as FEMEN have multiple versions and change over time, and Shachko's FEMEN is distinct from the FEMEN we see now. As she described in the 2013 documentary I Am Femen, in which she actively participated, the group emerged out of her relationship with Anna Hutsol and Alexandra Shevchenko in Khmeltnytskyi, and their discussions about the stereotypes about how women should behave and what roles they should play in life. Shachko says her first action as a feminist was in protest-with blood and sheets-to mismanagement at the local maternity hospital that led to the deaths of four women during childbirth in one day. ${ }^{4}$ Inspired by the attention they received, the three moved to Kyiv and engaged in their action as FEMEN, the 2008 street protest titled, "Ukraine is not a Brothel" which Shachko saw as a rebuke to the reputation that all Ukrainian women were prostitutes.

1. Vladimir Ivakhnenko, “'Ee ubil Parizh.' Zhizn' i smert' Oksany Shachko” ('Paris killed her:' Life and death of Oksana Shachko), Radio Svoboda, July 28, 2018, https://www.svoboda.org/a/29395701.html (accessed March 5, 2019).

2. Armelle Leturcq, "A Meeting with Oksana Shachko," Crash, Interview, November 2017, https://www.crash.fr/a-meeting-with-oksana-shachko/ (accessed November 5, 2018).

3. Ivakhnenko, "Ee ubil Parizh."

4. Leturcq, "A Meeting with Oksana Shachko." 
Shachko was the first to go topless, at a 2009 demonstration for Ukrainian Independence Day, with a Ukrainian flower wreathe in her hair. She embraced the topless protest, making it FEMEN's signature in some five dozen actions over the next few years. ${ }^{5}$ Early on, prominent protests in which Shachko took part included demonstrating against the former Ukrainian Prime Minister Yulia Tymoshenko for being "the same as Yanukovych," and against the 2012 UEFA Euro football championship which FEMEN feared would encourage prostitution (chanting "fuck Euro" in multiple locations). Other protestssuch as at the Kyiv zoo where animals were dying from the neglect due to the corruption of Ukrainian elites-are often forgotten. In 2011, Shachko and two other FEMEN members protested in front of the headquarters of the Belarus KGB to "save Belarus," a regime that Shachko saw as a corrupt and abusive dictatorship. In 2012, chanting "Putin is a thief," she attempted to abscond with the ballot box with Putin's vote for his return to the presidency. She was one of the protestors that confronted Putin as het met with German Chancellor Angela Merkel at a trade fair in Hanover. Outside of the region, where FEMEN's interventions were more sporadic, she protested the sexism she saw within Islam in Paris in 2011, at the World Economic Forum in Davos in 2012, and against Italian Prime Minister Silvio Berlusconi in 2013. Shachko claims to have left the group a year or so into its expansion-and-then move to Paris.

On the surface, the formula that Shachko honed for FEMEN is "at once simple and spectacular: scantily clad topless women stage highly theatrical demonstrations to draw attention to various facets of gender inequality in Ukraine." ${ }^{6}$ Seeing their actions as straightforward and primarily a part of civil society, analysis and opinions in the popular press have mostly wrestled with the question of whether a group that protests topless can really be feminist. Mainstream women's organizations and many feminists in the region have been particularly critical, seeing their "actions as simply giving men more of what they want," especially when FEMEN relies on women who have bodies like fashion models (as Shachko did). ${ }^{7}$ FEMEN was seen as distracting attention from other feminist groups in Ukraine, such as Ofenzywa, who protest clothed and whose ideology is more anchored in academic feminism. FEMEN has also been undermined by allegations in the 2013 documentary Ukraine Is Not a Brothel that Viktor Sviatsky was the puppeteer of the organization's actions, a claim Shachko denies in I am Femen. All these problems led some, such as Oksana Kis, to see FEMEN as having "nothing to do with feminism," even as it is now "unfortunately" associated in Ukraine with feminism. ${ }^{8}$ In 2017, Emily Channell-Justice suggested that FEMEN is irrelevant to Ukraine as

5. Jessica Zychowicz. "Performing Protest: Femen, Nation, and the Marketing of Resistance," JUPS-Journal of Ukrainian Politics and Society 1 (2015): 81.

6. Jessica Zychowicz, "Two Bad Words: FEMEN \& Feminism in Independent Ukraine,” Anthropology of East Europe Review 29, no. 2 (2011): 215-27.

7. Emily Channell, "Is Sextremism the New Feminism? Perspectives from Pussy Riot and Femen," Nationalities Papers 42, no. 4 (July 2014): 613; Valerie Sperling, Sex, Politics, and Putin: Political Legitimacy in Russia (Oxford, 2015), 241-44.

8. Oksana Kis': Zhinki chasto maiut' alergiiu na feminism (Oksana Kis: Women are Often Allergic to Feminism). Interv'iu z Ukraini (Interview with Ukraine), October 29, 2015, at https://rozmova.wordpress.com/2015/11/02/oksana-kis-2/ (accessed March 5, 2019). 
they did not participate in the EuroMaidan protests and discredited because of revelations that some of their funding came from men who pushed for women's topless protest. ${ }^{9}$

Even from this perspective, we would be remiss not to acknowledge the high price paid by Shachko (and her fellow protestors), despite their commitment to non-violence. In their early years in Ukraine, Shachko sometimes faced rough treatment from guards or police officers that would leave bruises or a bloody nose. In Belarus, she and two others were allegedly kidnapped for two days, brutally interrogated, forced to undress and pose for cameras with swastikas, and then left in a forest. ${ }^{10}$ Shachko was jailed for two weeks in Russia, interrogated by the FSB and banned from the country for life. In the years leading up to their exile-especially after the activists from the Russiabased feminist punk protest group Pussy Riot were sentenced to three years in labor camps-Shachko was increasingly afraid of being watched. She felt so terrorized that she broke her forearms getting away from what she thought were Ukrainian security forces. Her fear must have been acute, as the injury on her painting arm was so severe she required surgery.

However, Shachko frequently asserted that what FEMEN did was art, and she composed FEMEN's actions like feminist performance art. Especially from her perspective, their actions must be seen as performative, both in the sense of being theatrical and in Judith Butler's notion of performance as the central arena through which gender is defined and redefined. ${ }^{11}$ As Jessica Zychowicz has argued, their actions are "spectacle," made with clever "political parody"; using their bare breasts as histrionic weapons, women in FEMEN "typecast themselves into role-playing an oppressed female ideal in a theatre of the absurd."12 Describing herself as an "iconographer," Shachko created herself as one of the "iconic images of [the] movement," topless but wearing jeans, a power pose more like a modern Amazonian warrior taking on injustice than like the representations of women in most porn, which men can easily and freely get for themselves these days. FEMEN had emerged within the changed political context after Ukraine's 2004 Orange Revolution, which, among a small subset of the somewhat interconnected post-Soviet societies, energized street theater and the radical left, including feminisms. ${ }^{13}$ Even for Shachko, who began with a focus on gender stereotypes, FEMEN evolved to tackling repression by Putin and other strongmen in the region, who became more menacing in their fear of such popular uprisings. Women's civil society had been a target, and FEMEN at least implicitly understood that such

9. Emily S. Channell-Justice, “'We're Not Just Sandwiches’: Europe, Nation, and Feminist (Im) Possibilities on Ukraine's Maidan,” Signs: Journal of Women in Culture and Society 42, no. 3 (2017): 722n10.

10. Sam Wilson, “Ukraine’s Femen: Topless Protests 'Help Feminist Cause," BBC News, October 23, 2012, at https://www.bbc.com/news/world-europe-20028797 (accessed March 5, 2019).

11. Judith Butler, Gender Trouble: Feminism and the Subversion of Identity (New York, 2002).

12. Zychowic, "Two Bad Words," 217-18.

13. Alexandra Hrycak. "Orange Harvest?: Women's Activism and Civil Society in Ukraine, Belarus and Russia since 2004,” Canadian-American Slavic Studies 44, no. 1-2 (2010): 165-67. 
repression was gendered. As Valerie Sperling argues, Putin especially was branded as the tough guy that was needed to prevent chaos and then increasingly claimed the moral authority to protect the region from liberal threats such as homosexuality. ${ }^{14}$

FEMEN was not alone in their "sextremism," as FEMEN came to call it. Pussy Riot too employed female "sexual language and imagery as well as physical sexuality in protest of [patriarchy and] their current regimes." ${ }^{15}$ Both groups, resonating with the tradition of feminist performance art of the 1970s and 80 s in the West, played with masking and unmasking their faces and bodies to counter repressive narratives of women's representation. Nor were such provocative actions limited to women: in 2013, Petr Pavlensky posed naked wrapped in barbed wire and later nailed his scrotum to Red Square. ${ }^{16}$ While some blame FEMEN and Pussy Riot for "provoking" a negative reaction to feminism from the population, the energy of neo-traditionalism was already being mobilized by the illiberal populism propagated by Putin and other leaders in eastern Europe and being turned into a coherent "anti-gender" movement. ${ }^{17}$ In recent years, those illiberal forces have been so powerful that even established democracies have been undermined, suggesting broader economic, social, and political drivers than FEMEN.

Feminists in the region had already tried to be "good girls," organizing themselves into non-governmental organizations with staid projects conducted by middle-class, middle-aged professionals. Yes, there had been some small, notable successes. Alexandra Hrycak highlights how some women's organizations in Ukraine became avenues to formal politics or successfully lobbied for reform against gendered violence. ${ }^{18}$ There were also some prominent activists, such as Ruslana Lyzhychko, a widely popular singer-song writer, whose 2008 song "Not for Sale" was an anthem for anti-trafficking efforts. But, even in Ukraine, where some political parties openly embraced western norms and were seen as including feminism, this "foundation feminism" was too much for most people, and the impact was limited..$^{19}$ The guerrilla feminism of FEMEN and Pussy Riot tackle head-on the deceits and feints of the informal politics being used by regimes such as Ukraine under Yanukovych

14. Sperling, Sex, Politics, and Putin.

15. Channell, "Is Sextremism the New Feminism?," 611.

16. Shaun Walker, "Petr Pavlensky: Why I Nailed my Scrotum to Red Square," The Guardian, February 5, 2014, at https://www.theguardian.com/artanddesign/2014/feb/05/ petr-pavlensky-nailed-scrotum-red-square (accessed March 5, 2019).

17. Agnieszka Graff and Elżbieta Korolczuk, "Gender as 'Ebola from Brussels': The Anti-colonial Frame and the Rise of Illiberal Populism," Signs: Journal of Women in Culture and Society, vol. 43, no. 4 (2018): 797-821.

18. Katalin Fábián, Alexandra Hrycak, and Janet Elise Johnson, "Women’s/Feminist Activism, Russia, Ukraine and Eurasia," The Wiley Blackwell Encyclopedia of Gender and Sexuality Studies, Nancy A. Naples, ed., (Wiley Blackwell, 2016): 1-5, available online at https://doi.org/10.1002/9781118663219.wbegss437 (limited access).

19. Alexandra Hrycak, "Foundation Feminism and the Articulation of Hybrid Feminisms in post-Socialist Ukraine," East European Politics and Societies 20, no. 1 (February 2006): 69-100. 
and Russia under Putin. ${ }^{20}$ It also seems plausible that FEMEN helped create space for the variety of feminisms that have emerged in post-EuroMaidan Ukraine: from those who advocate for legislation, radical feminists who reject working with the state, and those who attempt to make feminism appealing to everyday Ukrainian women who might not think of themselves as feminist. ${ }^{21}$

According to Jacqueline Feldman, who had interviewed and befriended her, Shachko described her break with FEMEN "in aesthetic terms."22 Shachko saw herself as an activist but also as one of the "true artists ... [whose] main task ... is revolution.” Those who associated themselves with FEMEN once it was in exile no longer saw the performativity of their actions. Inna Shevchenko, who joined FEMEN in 2010 and is now the de facto head of FEMEN in Paris, denied that what they did was art, declaring breasts literal weapons. Shachko described FEMEN as the founders' whole lives while they were in Ukraine and accused those who were engaging recent actions in the name of FEMEN of being copycats who are "just manipulating people," not challenging the complex problematics that early FEMEN did.

What I find most problematic is FEMEN's one-dimensional take on patriarchy within Islam. To be fair to Shachko, most of the FEMEN protests against Islam happened after Shachko retired, and it is Inna Shevchenko who has been the most categorical in rejecting the possibility of feminisms within Islam, calling it "oxymoronic." ${ }^{23}$ Shachko's anti-Islam protest was at the invitation of a French feminist, in which she painted "Naked War" and "I am a woman and not an object" on her co-protestors' torsos, which were revealed under their burkas. ${ }^{24}$ Shachko was not the movement's ideologist, but it is her formula that sets up to see things so simplistically: if undressing is protest, then being covered up must be compliance. The role of coercion at work when state, religious, or paramilitary authorities force women to dress or undress, which I see as the real problem, is rendered invisible.

In Shachko's retirement from FEMEN, she explored this relationship between religion and patriarchy more deeply. In her 2016 Paris art premier, "Iconoclast," she exhibited fifteen paintings made with the technique and in the style of the icons she had learned in her youth, but this time she incorporated "her current convictions to denounce religious power and patriarchal

20. Janet Elise Johnson, The Gender of Informal Politics: Russia, Iceland and TwentyFirst Century Male Dominance (Cham, Switzerland, 2018).

21. Sean Guillory, "Feminists in the Maidan: Interview with Emily Channell-Justice," Sean's Russia Podcast, \#55, September 16, 2017, itunes: https://itunes.apple.com/us/podcast/seans-russia-blog/id597948126?mt=2\# (accessed March 5, 2019).

22. Jacqueline Feldman, "Notes on the Death of Oxana Shachko," The Paris Review, August 6, 2018, https://www.theparisreview.org/blog/2018/08/06/notes-on-the-death-ofoxana-shachko/ (last accessed March 10, 2019).

23. Decca Aitkenhead, "Femen leader Inna Shevchenko: 'I'm for any form of feminism,"” The Guardian, November 8, 2013, www.theguardian.com/world/2013/nov/08/ femen-leader-inna-shevchenko-interview (accessed March 10, 2019).

24. Dialika Neufeld, “The Body Politic: Getting Naked to Change the World," Spiegel, May 11, 2012, www.spiegel.de/international/europe/femen-activists-get-naked-to-raisepolitical-awareness-a-832028-2.html (accessed March 11, 2019). 
society." 25 Most of the icons stick to Christian themes, pointing out sanctimony, for example, with a version of Andrey Rublev's Trinity but with the three drinking and smoking. Perhaps most relevant here is her icon of Mary with Jesus suckling at one revealed breast, but Mary is in a burka, otherwise completely covered down to her black gloves. As with her apparent suicide, where her only explanation was a note "You are all fake," we are left with a visual riddle about representation, gender, and belief. ${ }^{26}$

JANET ELISE JOHNSON Brooklyn College, CUNY

25. Galerie Mansart art catalog, "Oksana Shachko: Icononclaste” (May 12-June 19, 2016), at www.galerie-mansart.fr/iconoclaste--oksana-shachko.html (accessed November 7, 2018).

26. Vladimir Ivakhnenko, "Ee ubil Parizh.” 